\title{
The Perceived Usefulness of Digital Simulators in the Acquisition of Professional Competencies by Undergraduate Nursing Students
}

\author{
https://doi.org/10.3991/ijet.v15i22.17023 \\ Rabia Qaisar ${ }^{(凶)}$ \\ Hassan II University, Casablanca, Morocco \\ Higher Institute of Nursing and Health Techniques of Casablanca (ISPITSC), \\ Casablanca, Morocco \\ rabiaqaisar9@gmail.com \\ Halima Lajane \\ Hassan II University, Casablanca, Morocco \\ Abderrahmane Lamiri \\ Hassan II University, Casablanca, Morocco \\ Higher Institute of Nursing and Health Techniques of Casablanca (ISPITSC), \\ Casablanca, Morocco \\ Hind. Bouzoubaa \\ Hassan II University, Casablanca, Morocco \\ Omar Abidi \\ Higher Institute of Nursing and Health Techniques of Casablanca (ISPITSC), \\ Casablanca, Morocco \\ Abderrahim Khyati \\ Hassan II University, Casablanca, Morocco
}

\begin{abstract}
Digital virtual simulators are considered one of the most innovative teaching methods currently available for overcoming training difficulties in clinical nursing practice. This study aimed to measure the perceived usefulness of digital simulators in the acquisition of professional nursing skills among undergraduate nursing students. A group of 50 students participated in an online training module on a digital simulator over six sessions. They then responded to a survey about the training. The results indicated that $80 \%$ of the participants found learning with a digital simulator to be an enriching experience and $82 \%$ of the students felt that it could be beneficial to adopt this mode of teaching in other areas of nursing education. It is hoped that these findings will encourage teachers to adopt this approach to nursing education as a solution to the various constraints related to student placements. It may be especially useful in situations where there is a lack of supervisors or a large number of students.
\end{abstract}


Keywords - Digital simulator, perception, nursing process, professional skills

\section{Introduction}

The education of nursing students in the implementation of a process of care is one of the most important cornerstones of nursing education [1]. The nursing process is a well-structured, scientific approach to problem-solving comprising a set of ordered steps (assessment, diagnosis, planning, implementation and evaluation). The nursing student must master these steps in order to meet the needs of patients in a changing care environment [2].

The application of the nursing process in clinical settings requires mobilisation of the knowledge and skills learnt in training in a variety of professional situations [3]. However, research suggests that most students lack the knowledge to implement individualised care plans [4], and the critical thinking and reflective skills required for appropriate nursing diagnoses [5,6].

Digital simulators are considered one of the most innovative educational approaches currently available to overcome these problems in clinical nursing education $[7,8]$. A virtual simulation of the clinical environment provides an interactive experience in which students can apply their theoretical learning $[9,10]$. This technology also helps students to develop critical thinking [11] and clinical reasoning skills in a meaningful and reassuring environment $[12,13]$. It helps teachers to cope with constraints relating to placement sites, such as a lack of supervisory staff. It will be particularly useful in this regard going forward since van Graan et al. [6] have found that the number of nursing students is increasing and this will make suitable placements even more difficult to secure for every student. There is, therefore, an increasing need for innovative alternative teaching strategies that will circumvent these obstacles to learning. The use of digital simulators is ideal for this purpose.

In Morocco, the reform of paramedical studies in 2013 led to the creation of a number of higher education institutions, collectively named the Higher Institutes of Nursing Professions and Health Techniques (ISPITS) [14]. However, there has been little change to the pedagogical formulas adopted by teachers [15]. Furthermore, there has been a dearth of research exploring the potential use of digital simulators in the acquisition of professional nursing skills. Until now, there have been no studies of digital simulation as a teaching aid for student nurses in Morocco. Thus, the aim of this study was to measure nursing students' perceptions of digital simulator-based learning

\section{Research Methodology}

\subsection{Ethical consideration}

Institutional approval was obtained to conduct this study by the Ministry of Health and the Directorate of ISPITS of Casablanca. Participation was voluntary and no student was exposed to harm. Anonymity and confidentiality of data were respected. 


\subsection{Study design}

This study was exploratory and quantitative. The population sampled was nursing students $(\mathrm{n}=50)$ who participated in learning sessions on a digital simulator during the 2019/2020 academic year.

\subsection{Participants and framework}

The course taught on the digital simulator took place over six sessions between April and June 2020. The participants were nursing students in the second semester of their training at the Higher Institute of Nursing Professions and Health Techniques Casablanca in Morocco, which leads to a professional license.

\subsection{Procedure}

Before each simulator-based teaching intervention, the students were invited to the course on the "Google Classroom" platform. The teaching material was delivered in the form of interactive presentations, videos and lectures on "Google Meet". Problemsolving activities (case studies with standard answer keys) were replaced by online interaction with a virtual patient.

All participating students were asked to install the necessary application on their personal computers or tablets through the "Medicactiv" platform, which was accessible online via a space created by the Institute. The teacher delivering the module instructed the students on using the application to access to the chosen simulator. The clinical simulator provided an orientation tutorial and four clinical situations in which students were required to complete the following activities: a) Collect data in accordance with Virginia Henderson's model by listening carefully to the interview with the virtual patient with decompensating chronic obstructive pulmonary disease, b) Perform a clinical examination, c) Improve clinical reasoning, d) Make a nursing diagnosis, e) Establish a care plan, d) Complete quizzes and answer test questions.

Students were able to view their results after participation in each clinical situation to assess their progress. They had the option to repeat the training as many times as they chose within a specific time frame to achieve the learning objectives.

\subsection{Measuring instrument}

Towards the end of the module, students were asked to complete a questionnaire on their perceptions of learning with a digital simulator. The questionnaire content was developed based on a literature review $[16,17]$ and adopted to the questionnaire of Howard et al. [17]. The measurement instrument consisted of 17 statements, each of which was to be rated on a Likert scale ranging from 1 to 5 (strongly agree, agree, unsure, disagree, and strongly disagree).

Four permanent teachers with graduate degrees validated the content of the questionnaire. All of the four specialise in ISPITS paramedical education and have at least 
two years' experience with simulation-assisted teaching. A doctor with expertise in numerical simulation further validated the content.

A pre-test was conducted with ten nursing students to ensure the clarity of the statements and respondent comprehension. The internal consistency of the scale was calculated and a Cronbach's alpha score of 0.914 obtained.

\subsection{Statistical analysis}

Data analysis was performed using SPSS statistical software (version 23.0). The results are presented in tables 1,2 and figures 3 .

\section{$3 \quad$ Results}

\subsection{Demographic characteristics of the participants}

A total of 50 nursing students took part in the study. Participants were predominantly female, with an average age of 18 years (Table 1 ).

\begin{tabular}{llcc} 
& \multicolumn{1}{c}{ socio-demographic characteristics } & $\begin{array}{c}\text { Nombre } \\
(\mathrm{N}=50)\end{array}$ & $\begin{array}{c}\text { Pourcentage } \\
\%\end{array}$ \\
\hline Gender & Male & 4 & $8 \%$ \\
& Female & 46 & $92 \%$ \\
\hline \multirow{2}{*}{ Options } & Neonatal Nurse & 7 & $14 \%$ \\
& Anaesthesia and Resuscitation Nurse & 5 & $10 \%$ \\
& Family and Community Health Nurse & 9 & $18 \%$ \\
& Emergency and Intensive Care Nurse & 5 & $10 \%$ \\
& Versatile Nursing & 24 & $48 \%$ \\
\hline \multirow{2}{*}{ Students mean age (in years) $\pm \mathrm{SD}$} & & $(18,38 \pm 0,490)$
\end{tabular}

\subsection{Results of student survey}

Survey responses indicated $80 \%$ of the participants found learning the steps of the nursing process on a digital simulator to be useful. The quizzes on the digital simulator students were thought to have helped them to remedy shortcomings by $72 \%$ of respondents. The digital simulator was acknowledged as a source of immediate constructive feedback by $76 \%$ of respondents and $72 \%$ felt that it enabled them to apply their theoretical learning. In terms of perceived skill acquisition, $74 \%$ felt the simulator had helped them to acquire clinical reasoning skills, $64 \%$ felt it had contributed to their critical thinking skills, $78 \%$ believed it had improved their problem-solving skills and $72 \%$ felt it had improved their decision-making skills when making a nursing diagnosis.

The percentage of respondents who felt the simulator had provided them with an opportunity to practice was $76 \%$ (Table 2 ). 


\begin{tabular}{|c|c|c|c|c|c|c|c|}
\hline Items & $\begin{array}{l}\text { Strongly } \\
\text { Agree } \\
(\%)\end{array}$ & $\begin{array}{l}\text { Agree } \\
(\%)\end{array}$ & $\begin{array}{l}\text { Unsure } \\
(\%)\end{array}$ & $\begin{array}{c}\text { Disagree } \\
(\%)\end{array}$ & $\begin{array}{l}\text { Strongly } \\
\text { disagree } \\
(\%)\end{array}$ & Mean & SD \\
\hline $\begin{array}{l}\text { 1/ The digital simulator enriched my theoretical } \\
\text { knowledge of the nursing process. }\end{array}$ & 34 & 42 & 14 & 6 & 4 & 2.04 & 1.049 \\
\hline $\begin{array}{l}\text { 2/ The digital simulator was a useful strategy for } \\
\text { teaching the steps of the nursing process }\end{array}$ & 30 & 50 & 12 & 6 & 2 & 2.00 & 0.925 \\
\hline $\begin{array}{l}\text { 3/ The digital simulator helped me to achieve my } \\
\text { learning goals. }\end{array}$ & 28 & 38 & 12 & 12 & 10 & 2.38 & 1.291 \\
\hline $\begin{array}{l}\text { 4/ I feel that learning on a digital simula tor could be } \\
\text { beneficial in other areas of the training curriculum. }\end{array}$ & 38 & 44 & 8 & 8 & 2 & 1.92 & 0.986 \\
\hline $\begin{array}{l}\text { 5/ The digital simulator allowed me to put my } \\
\text { theoretical knowledge into practice. }\end{array}$ & 28 & 44 & 14 & 8 & 6 & 2.20 & 1.124 \\
\hline $\begin{array}{l}\text { 6/ The digital simulator helped me to develop } \\
\text { clinical reasoning skills. }\end{array}$ & 32 & 42 & 8 & 14 & 4 & 2.16 & 1.149 \\
\hline $\begin{array}{l}7 / \text { The digital simulator helped me to develop } \\
\text { critical thinling skills. }\end{array}$ & 28 & 36 & 12 & 14 & 10 & 2.42 & 1.310 \\
\hline $\begin{array}{l}\text { 8/ The digital simulator helped me to develop } \\
\text { problem-solving skills. }\end{array}$ & 28 & 50 & 08 & 12 & 2 & 2.10 & 1.015 \\
\hline $\begin{array}{l}\text { 9/ The digital simulator helped with my decision - } \\
\text { maling when making nursing diagnoses. }\end{array}$ & 36 & 36 & 14 & 12 & 2 & 2.08 & 1.085 \\
\hline $\begin{array}{l}10 / \text { The digital simulator was an opportunity to } \\
\text { practice with virtual patients before working with } \\
\text { real patients. }\end{array}$ & 32 & 44 & 8 & 10 & 06 & 2,14 & 1.160 \\
\hline $\begin{array}{l}\text { 11/ Learning on a digital simulator has been an } \\
\text { enriching experience. }\end{array}$ & 22 & 58 & 10 & 4 & 6 & 2.14 & 1.010 \\
\hline $\begin{array}{l}\text { 12/ I found the virtual environment within the } \\
\text { digital simulator to be closer to the reality of the } \\
\text { clinical environment. }\end{array}$ & 22 & 36 & 18 & 16 & 8 & 2.52 & 1.232 \\
\hline $\begin{array}{l}\text { 13/ The digital simulator allow ed me to focus on the } \\
\text { simulated clinical case study. }\end{array}$ & 32 & 26 & 12 & 20 & 10 & 2.50 & 1.388 \\
\hline $\begin{array}{l}14 / \text { I found that the digital simulator allowed me to } \\
\text { actively engage in the learning process. }\end{array}$ & 14 & 42 & 14 & 24 & 6 & 2.66 & 1.171 \\
\hline $\begin{array}{l}\text { 15/ The quizzes on the digital simulator helped me } \\
\text { to id entify and remedy my shortcomings. }\end{array}$ & 32 & 40 & 16 & 6 & 6 & 2.14 & 1.125 \\
\hline $\begin{array}{l}\text { 16/ The digital simulator provided immediate } \\
\text { constructive feedback }\end{array}$ & 34 & 42 & 10 & 10 & 4 & 2.08 & 1.103 \\
\hline $\begin{array}{l}17 / \text { The digital simulator helped me to evaluate my } \\
\text { learning progress. }\end{array}$ & 28 & 42 & 14 & 12 & 4 & 2.22 & 1.111 \\
\hline TOTAL & $29,29 \%$ & $41,88 \%$ & $12 \%$ & $11,41 \%$ & $5,41 \%$ & 2,22 & 1,178 \\
\hline
\end{tabular}

\subsection{Students' total perception of digital simulator learning}

Figure 3 shows that $71.18 \%$ (41, 88\% agree, 29, $29 \%$ strongly agree) from total students had a positive perception of learning the Nursing Planning module through the digital simulator, $12 \%$ had an unsure perception and $16.82 \%(5,41 \%$ strongly disagree, 11, 41\% disagree) had a negative perception with total (Mean 2,22 $\pm 1,178$ ). 


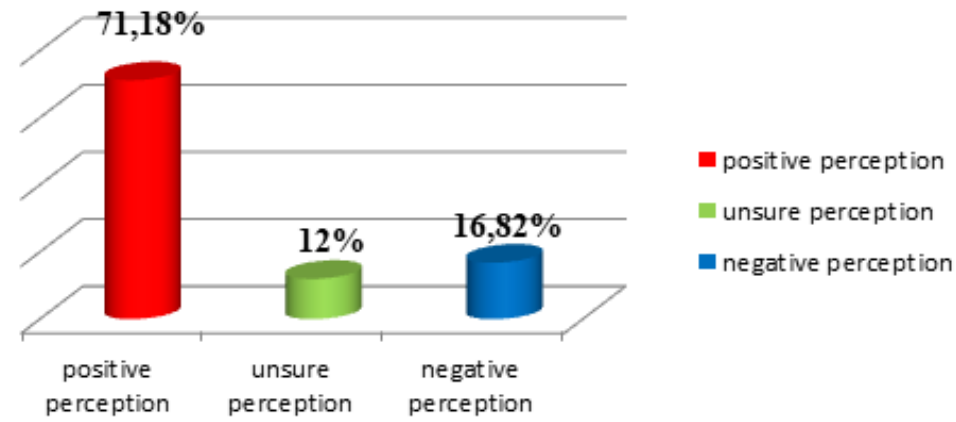

\section{Discussion}

The majority of the nursing students who participated in this study found interaction with a virtual clinical environment a useful teaching strategy that helped them acquire knowledge and skills of the nursing process. These findings are consistent with previous research. Nursing students in a study by Awad et al. [18] demonstrated positive attitudes toward technology-based clinical simulation learning and felt it helped the development of their nursing skills and collaborative work skills and increased their self-confidence concerning their abilities as nurses. Studies adilha et al. [19] and Dubovi [20] have shown clinical simulation-assisted instruction to be an effective teaching approach that improves long-term knowledge retention, recall, satisfaction with training and clinical reasoning.

In the present study, $76 \%$ of the students liked the feedback on the simulator and felt they helped them to progress. This supports Carter's [21] findings that learning through clinical simulation develops critical and clinical thinking skills more effectively than traditional teaching methods. Carter suggests that this is due to the beneficial effects of the immediate feedback provided by the digital simulator. Abdullah et al. [22] have also stipulated that feedback is a catalyst for success.

\section{Conclusion}

This study showed that nursing students find training provided through a digital virtual simulator to be beneficial and feel it improves their professional knowledge and nursing skills. It is hoped that these results will encourage teachers to take advantage of this technology in nursing training as a means of overcoming problems with internships, such as lack of available supervision when the student/teacher ratio is high. These findings may also encourage heads of institutions to commission the design of digital platforms and virtual pedagogical scenarios adapted to the nursing training program in Morocco and to Moroccan culture. 


\section{Acknowledgement}

We would like to thank the management of both ISPITS Casablanca-Settat and "SimforHealth" for their help and technical and administrative support.

\section{$7 \quad$ References}

[1] H. K. Burns, J. O’Donnell, et J. Artman, «High-fidelity Simulation in Teaching Problem Solving to 1st-Year Nursing Students», Clinical Simulation in Nursing, vol. 6, n 3, p. e87-e95, May 2010, https://doi.org/10.1016/j.ecns.2009.07.005

[2] B. J. Ackley, G. B. Ludwig, M. B. F. Makic, «Nursing Diagnosis Handbook an EvidenceBased Guide to Planning», p. 1061, 2017.

[3] M. E. Doenges, M. F. Moorhouse et A. C. Murr, Nursing Care Plans: Guidelines for Individualizing Client Care Across the Life Span, $9^{\mathrm{e}}$ éd. 2014.

[4] R. Gouifrane, H. Lajane, S. Benmokhtar, F. Dehbi, et M. Radid, « Investigating Learning Challenges from the Perspective of Nursing Students and Educators at a University in Casablanca, Morocco », TONURSJ, vol. 14, n 1, p. 109-119, juin 2020, https://doi.org/10.2174 $\underline{1874434602014010109}$

[5] F. Taskin Yilmaz, S. Sabanciogullari, et K. Aldemir, «The Opinions of Nursing Students Regarding the Nursing Process and Their Levels of Proficiency in Turkey», J Caring Sci, vol. 4, n 4, p. 265-275, Dec. 2015, https://doi.org/10.15171/jcs.2015.027

[6] A. C. van Graan, M. J. S. Williams, et M. P. Koen, «Professional nurses' understanding of clinical judgement: A contextual inquiry », Health SA Gesundheit, vol. 21, p. 280-293, Dec. 2016, https://doi.org/10.1016/j.hsag.2016.04.001

[7] National League for Nursing (NLN), « A vision for Teaching with Simulation», 2015.

[8] B. Batchakui, V. Monthe, etc. Tangha, «MV-SYDIME: A Virtual Patient for Medical Diagnosis Apprenticeship», Int. J. Onl. Eng., vol. 8, no 4, p. 21-31, Nov. 2012, https://doi.org/10.3991/ijoe.v8i4.2159.

[9] B. K. Robinson et V. Dearmon, «Evidence-Based Nursing Education: Effective Use of Instructional Design and Simulated Learning Environments to Enhance Knowledge Transfer in Undergraduate Nursing Students», Journal of Professional Nursing, vol. 29, no 4, p. 203-209, Jull. 2013, https://doi.org/10.1016/j.profnurs.2012.04.022

[10] Kustandi, D. N. Fadhillah, R. Situmorang, D. S. Prawiladilaga, et S. Hartati, « VR Use in Online Learning for Higher Education in Indonesia », Int. J. Interact. Mob. Technol., vol. 14, no 01, p. 31, janv. 2020, Doi: 10.3991/ijim. v14i01.11337.

[11] [M. Rababa et D. Masha 'al, « Using branching path simulations in critical thinking of pain management among nursing students: Experimental study », Nurse Education Today, vol. 86, p. 104323, mars 2020, https://doi.org/10.1016/j.nedt.2019.104323

[12] X. Bai et J. Lavin, « Understanding Social Learning Behaviors via a Virtual Field Trip», Int. J. Emerge. Technol. Learn., vol. 9, n 4, p. 4, juin 2014, https://doi.org/10.3991/ ijet.v9i4.1205

[13] P. Quist et al., « Design of Virtual Learning Environments: Learning Analytics and Identification of Affordances and Barriers», Int. J. Eng. Ped., vol. 5, no 4, p. 64, oct. 2015, https://doi.org/10.3991/ijep.v5i4.4962

[14] Minister de la Santee - Maroc. Décret-Création_ISPITS_6.pdf. Maroc; 2013:6507 
[15] S. Abouzaj, « Competency-Based Approach in Training Nurses and Midwives in Morocco Demystify to Better Use », Adv Med Educ Pract, vol.10, p. 1069-1079, Dec. 2019, https://doi.org/10.2147/amep.s200685

[16] H. Shin, D. Rim, H. Kim, S. Park, et S. Shon, «Educational Characteristics of Virtual Simulation in Nursing: An Integrative Review», Clinical Simulation in Nursing, vol. 37, p. 18-28, Dec. 2019, https://doi.org/10.1016/j.ecns.2019.08.002.

[17] V. M. Howard, C. Ross, A. M. Mitchell, et G. M. Nelson, «Human Patient Simulators and Interactive Case Studies: A Comparative Analysis of Learning Outcomes and Student Perceptions», CIN: Computers, Informatics, Nursing, vol. 28, n 1, p. 42-48, janv. 2010, https://doi.org/10.1097/ncn.0b013e3181c04939

[18] M. S. Awadh, M. K. Abdullah, R. H. Ibrahim, et R. K. Abdulla, «Nursing Students’ Attitudes Toward Simulation Technology in Nursing Education», Int. J. Emerge. Technol. Learn., vol. 14, n 14, p. 31, Jull. 2019, https://doi.org/10.3991/ijet.v14i14.10571.

[19] J. M. Padilla, P. P. Machado, A. Ribeiro, J. Ramos, et P. Costa, «Clinical Virtual Simulation in Nursing Education: Randomized Controlled Trial», J Med Internet Res, vol. 21, n 3, p. e11529, mars 2019, https://doi.org/10.2196/11529.

[20] M. D. Carter, «The effects of computer-based simulations on speech-language pathology student performance», Journal of Communication Disorders, vol. 77, p.44-55, janv. 2019 , https://doi.org/10.1016/j.jcomdis.2018.12.006

[21] M. Y. Abdullah, S. Hussain, et M. Shakir, «The Effect of Peers' and Teacher's E-Feedback on Writing Anxiety Level Through CMC Applications», Int. J. Emerge. Technol. Learn., vol. 13, n 11, p. 196, Nov. 2018, https://doi.org/10.3991/ijet.v13i11.8448.

[22] [I. Dubovi, «Designing for online computer-based clinical simulations: Evaluation of instructional approaches», Nurse Education Today, vol. 69, p. 67-73, oct. 2018, https://doi.org/10.1016/j.nedt.2018.07.001

\section{Authors}

Rabia Qaisar is a Ph. Dc in Educational Technology. She is a Nurse Teacher at Higher Institute of Nursing and Health Techniques of Casablanca. She is a member at Interdisciplinary Group of Didactics of Science \& Educational Sciences (GIDS), École Normale Supérieure, Hassan II University. She is a member of the Multidisciplinary Laboratory in Sciences ( and Information Communication and Education Technology (LAPSTICE) at Ben M'Sik Faculty of Sciences, Hassan II University of Casablanca, Morocco. She is a member of Association for the Development of Evaluation Methodologies in Education (ADMEE)-Section Morocco. Email: rabiaqaisar9@gmail.com

Halima Lajane is a Ph. Dc in Educational Technology. She is a Nurse Teacher and the head of continuing education office at Ibn Rochd hospital of Casablanca, Morocco. She is a member of Association for the Development of Evaluation Methodologies in Education (ADMEE)-Section Morocco. She is a member of Laboratory of Physical Chemistry of Materials (LCPM) at Ben M'Sik Faculty of Sciences, Hassan II University of Casablanca, Morocco.

Abderrahmane Lamiri is a $\mathrm{Ph}$. Dc in Educational Technology. He is a Nurse Teacher at Higher Institute of Nursing and Health Techniques of Casablanca. He is a member at Interdisciplinary Group of Didactics of Science \& Educational Sciences 
(GIDS), École Normale Supérieure, Hassan II University of Casablanca, Morocco. He is a member of Association for the Development of Evaluation Methodologies in Education (ADMEE)-Section Morocco. He is a member of the Multidisciplinary Laboratory in Sciences and Information Communication and Education Technology (LAPSTICE) at Ben M'Sik Faculty of Sciences, Hassan II University.

Hind Bouzoubaa is a PhD Biological and Pharmacological Sciences. She is a Professor. Researcher at Biological Department, at Faculty of Sciences Ben M'Sik, University Hassan II of Casablanca, Morocco, B.P 7955 Sidi Othman. She operates in several fields of biological sciences, teaching techniques and assessment. She is a member of Association for the Development of Evaluation Methodologies in Education (ADMEE) - section Morocco and the Multidisciplinary Laboratory in Sciences and Information Communication and Education Technology (LAPSTICE).

Omar Abidi is a Professor at the Higher Institute of Nursing and Health Techniques of Casablanca, Ministry of Health, Rue Faidouzi Mohamed (ex-rue JENNER), Casablanca, Morocco. He is a member of Interdisciplinary Group of Didactics of Science \& Educational Sciences GIDS, École Normale Supérieure, Hassan II University, Casablanca, Morocco.

Abderrahim Khyati is a Professor of Higher Education, Head of de Research team in the interdisciplinary group Science Didactics GIDS, École Normale Supérieure, Hassan II university of Casablanca. He is a member of the Multidisciplinary Laboratory in Sciences and Information Communication and Education Technology (LAPSTICE), at Faculty of Sciences Ben M'Sik, Hassan II university of Casablanca, Morocco.

Article submitted 2020-07-14. Resubmitted 2020-08-01. Final acceptance 2020-08-02. Final version published as submitted by the authors. 